\title{
Influence of local habitat features on disease avoidance by Caribbean spiny lobsters in a casita-enhanced bay
}

\author{
Patricia Briones-Fourzán ${ }^{1, *}$, Rebeca I. Candia-Zulbarán ${ }^{1}$, Fernando Negrete-Soto ${ }^{1}$, \\ Cecilia Barradas-Ortiz ${ }^{1}$, Juan P. Huchin-Mian ${ }^{2}$, Enrique Lozano-Álvarez ${ }^{1}$ \\ ${ }^{1}$ Unidad Académica de Sistemas Arrecifales, Instituto de Ciencias del Mar y Limnología, \\ Universidad Nacional Autónoma de México. Prol. Av. Niños Héroes s/n, Puerto Morelos, Quintana Roo 77580, Mexico \\ ${ }^{2}$ Laboratorio de Inmunología y Biología Molecular, Centro de Investigación y de Estudios Avanzados del Instituto \\ Politécnico Nacional-Unidad Mérida, Km 6 Antigua Carretera a Progreso, CORDEMEX, Mérida, Yucatán 97310, Mexico
}

\begin{abstract}
In Bahía de la Ascensión, Mexico, 'casitas' (large artificial shelters) are extensively used to harvest Caribbean spiny lobsters Panulirus argus. After the discovery of a pathogenic virus, Panulirus argus virus 1 (PaV1), in these lobsters, laboratory experiments revealed that PaV1 could be transmitted by contact and through water, and that lobsters avoided shelters harboring diseased conspecifics. To examine these issues in the context of casitas, which typically harbor multiple lobsters of all sizes, we examined the distribution and aggregation patterns of lobsters in the absence/presence of diseased conspecifics (i.e. visibly infected with PaV1) in 531 casitas distributed over 3 bay zones, 1 poorly vegetated ('Vigía Chico', average depth: $1.5 \mathrm{~m}$ ) and 2 more extensively vegetated ('Punta Allen': 2.5 m; 'Los Cayos': $2.4 \mathrm{~m}$ ). All zones had relatively high indices of predation risk. Using several statistical approaches, we found that distribution parameters of lobsters were generally not affected by the presence of diseased conspecifics in casitas. Interestingly, however, in the shallower and less vegetated zone (Vigía Chico), individual casitas harbored more lobsters and lobsters were actually more crowded in casitas containing diseased conspecifics, yet disease prevalence was the lowest in lobsters of all sizes. These results suggest that (1) investment in disease avoidance by lobsters is partially modulated by local habitat features, (2) contact transmission rates of PaV1 may be lower in nature than in the laboratory, and (3) water-borne transmission rates may be lower in shallow, poorly vegetated habitats more exposed to solar ultraviolet radiation, which can damage viral particles.
\end{abstract}

KEY WORDS: Panulirus argus - Panulirus argus virus 1 PaV1 - Casitas · Marine vegetation · Predation risk $\cdot$ Habitat features Resale or republication not permitted without written consent of the publisher

\section{INTRODUCTION}

The spiny lobster Panulirus argus (Latreille, 1804) is a valuable fishing resource across the wider Caribbean region and accounts for approximately $50 \%$ of the world catch of spiny lobsters (Phillips \& Melville-Smith 2006). Around 2000, wild populations of $P$. argus began being affected by a pathogenic virus, Panulirus argus virus 1 (PaV1) (Shields \&
Behringer 2004), which is currently widespread across the Caribbean (review in Behringer et al. 2011). Lobsters visibly infected with PaV1 (i.e. diseased) exhibit a white, milky hemolymph that fails to clot and, occasionally, a reddish discoloration over the exoskeleton (Shields \& Behringer 2004, LozanoÁlvarez et al. 2008). Highly infected lobsters become lethargic and eventually die from metabolic waste (Shields 2011). To date, no other hosts or reservoirs 
for PaV1 have been identified (Butler et al. 2008, Shields 2011).

Prevalence of PaV1 tends to decrease with increasing size of lobsters (Shields \& Behringer 2004, Lozano-Álvarez et al. 2008, Behringer et al. 2011, Cruz-Quintana et al. 2011). The individuals most susceptible to PaV1 are the smaller juveniles, which are widely dispersed in the settlement habitat (marine vegetation) and are asocial. After a few months, the juveniles emerge from the vegetation to seek hard structures that afford them a more adequate refuge for their larger size. At this point, lobsters become social and tend to aggregate in shelters. Chemical cues released in the urine of sheltered lobsters attract other conspecifics seeking shelter (Ratchford \& Eggleston 1998, Horner et al. 2006), thus reducing their time of exposure to predators (Childress \& Herrnkind 2001). Moreover, shelter-sharing individuals use their long, spiny antennae in concert to fend off approaching enemies ('group defense behavior'; Herrnkind et al. 2001), thus increasing per capita survival. PaV1 can be transmitted by contact, by ingestion of infected tissues, and through water (Butler et al. 2008). However, in the laboratory, lobsters were found to be able to detect and avoid shelters occupied by diseased conspecifics; similarly, in Florida Bay, most visibly infected lobsters were found alone (94\% solitary) in individual shelters (mostly large sponges and solution holes) (Behringer et al. 2006, Behringer $\&$ Butler 2010). Thus, it has been proposed that avoidance of disease by potential lobster hosts may lower the prevalence of disease by reducing contact transmission rates of PaV1 (Behringer et al. 2006).

However, investment in avoidance measures pays off for potential hosts only when the cost of avoidance is lower than the cost of infection (Thieltges \& Poulin 2008). Because predation is the most important cause of mortality for juvenile lobsters (Smith \& Herrnkind 1992), investment in avoidance of disease may depend to some extent on local extrinsic factors such as shelter availability, shelter size, and level of predation risk. For example, Lozano-Álvarez et al. (2008) recorded a high level of cohabitation between healthy and diseased lobsters in experimental casitas (large artificial shelters) deployed over a habitat poor in natural shelter. These authors hypothesized that, in the immediate absence of alternative shelters, lobsters would make a trade-off between the risk of infection (sharing a shelter with a diseased conspecific) and the risk of predation (foregoing that shelter and resuming the search for another shelter).

In Bahía de la Ascensión (Mexico), commercial casitas have been used to harvest Panulirus argus lob- sters for more than $50 \mathrm{yr}$. This particular fishery has remained remarkably sustainable, mostly due to the organizational scheme devised by the local fishing cooperative (Briones-Fourzán et al. 2000, Sosa-Cordero et al. 2008). Briefly, the bottom of the bay is partitioned into individual fishing parcels ('campos') allotted to individual fishers, who are free to deploy as many casitas as they see fit within their campos but cannot fish in someone else's campos. Currently, there are $\sim 18600$ casitas distributed over 108 campos, with distances between adjacent casitas ranging from 25 to $>50 \mathrm{~m}$. Fishing regulations include a $4 \mathrm{mo}$ closed season (March 1 to June 30), a prohibition on catching ovigerous females, and a minimum legal size of $135 \mathrm{~mm}$ tail (abdominal) length ( 74 mm carapace length, CL). Commercial casitas are 1.5 to $2 \mathrm{~m}^{2}$ in area and 10 to $15 \mathrm{~cm}$ in height because they target legal-sized lobsters. However, due to the highly gregarious nature of $P$. argus, commercial casitas usually harbor the full size range of lobsters, from small juveniles to adults (9-150 mm CL) (Lozano-Álvarez et al. 1991, Candia-Zulbarán et al. 2012, this DAO Special).

Field experiments have shown that casitas do not merely concentrate the existing lobster biomass but actually increase lobster biomass by enhancing survival of the full size range of lobsters that co-occupy casitas (Eggleston et al. 1990, Eggleston \& Lipcius 1992, Mintz et al. 1994, Briones-Fourzán \& LozanoÁlvarez 2001, Briones-Fourzán et al. 2007). However, as PaV1 can be transmitted by contact, we began an investigation into the dynamics of the PaV1 disease in the population of Panulirus argus from Bahía de la Ascensión. Partial results showed that disease prevalence varied widely in space and time (Candia-Zulbarán et al. 2012). In the present study, we examined whether the distribution and aggregation patterns of lobsters differed in the presence/absence of diseased conspecifics in casitas as well as the potential influence of local habitat features and levels of predation risk on these patterns and on local disease prevalence. We then formulated a hypothesis that could explain our findings and reconcile them with previous laboratory and field findings from elsewhere.

\section{MATERIALS AND METHODS}

\section{Study area}

Bahía de la Ascensión is a large $\left(760 \mathrm{~km}^{2}\right)$, shallow bay (average depth: $3.5 \mathrm{~m}$, maximum depth: $7 \mathrm{~m}$ ) located on the Mexican Caribbean coast (Quintana 
Roo) (Fig. 1). The bay is bordered by extensive wetlands, in particular mangrove forests, and several mangrove keys lie approximately at the bay center. The bay has relatively calm waters because an interrupted coral reef that runs parallel to the mouth of the bay reduces wave surge. Large expanses of the bay are covered by extensive meadows of mixed seagrasses (mainly Thalassia testudinum) and macroalgae, offering a good settlement habitat for postlarvae of Panulirus argus. In general, vegetation cover tends to decrease from the back-reef areas towards the innermost part of the bay, and from the margins to the center of the bay (Arellano-Méndez et al. 2011). The only human settlement along the entire margin of the bay is a small fishing village (population 600) (Fig. 1).

\section{Sampling operations}

We sampled hundreds of casitas from numerous 'campos' distributed over 3 large zones within the bay, called for convenience 'Punta Allen', 'Los Cayos', and 'Vigía Chico' (Fig. 1). In Punta Allen and Vigía Chico, samplings were conducted during 2

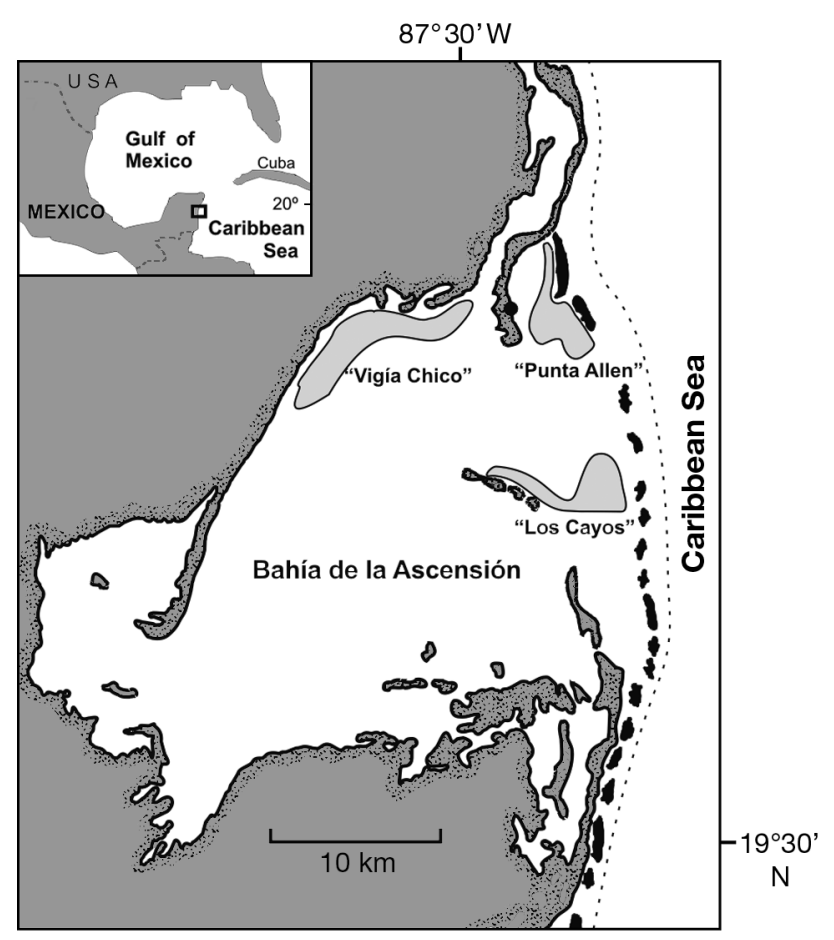

Fig. 1. Bahía de la Ascensión, showing the approximate location of the 3 Panulirus argus sampling zones (light grey), the coral reef (line of black patches off the mouth of the bay), the $100 \mathrm{~m}$ isobath (broken line), and the fishing village (black dot). Inset shows the location of Bahía de la Ascensión (small square) in Mexico fishing seasons (FS1: November 2008-February 2009; FS2: December 2009-February 2010) and 2 closed seasons (CS1: April 2009; CS2: May 2010). For logistic reasons, samplings in Los Cayos were only conducted during CS1 and CS2 (see Candia-Zulbarán et al. 2012).

Sampling operations were conducted by 2 teams in separate boats. Starting in different parts of a zone, each team sailed along transects roughly perpendicular to the nearest coast and surveyed all casitas encountered en route by skin-diving. All lobsters occupying a given casita were extracted with hand nets and carefully introduced into a large mesh bag. To minimize exposure of lobsters to air, the bag was kept under water, hanging from the side of the boat. One by one, the lobsters were extracted from the bag, measured $(C L)$ with a vernier caliper $( \pm 0.1 \mathrm{~mm})$, inspected for visible signs of the PaV1 disease (milky hemolymph, visible through the transparent membrane between the cephalothorax and abdomen, and a reddish discoloration of the exoskeleton), and immediately returned to the casita.

We estimated prevalence based on visible (clinical) signs of PaV1-infection because this considerably reduces handling stress for lobsters, and it is the visibly infected lobsters which mostly elicit avoidance behavior (Behringer et al. 2006, Behringer \& Butler 2010). However, as clinical prevalence does not account for subclinically infected individuals (i.e. lobsters that are infected but not diseased), we hereafter refer to visibly infected lobsters as 'diseased lobsters' and to non-visibly infected lobsters as 'nondiseased lobsters'.

\section{Habitat features and predation risk}

We used a hand-held digital sonar to measure the depth $( \pm 5 \mathrm{~cm})$ at which individual casitas were situated and recorded the type of bottom ('Hard': calcareous pavement, coral rubble; 'Soft': sand, mud) surrounding each casita to the extent of underwater visibility. We further categorized hard and soft bottoms into 4 general subtypes based on qualitative features ('bare': no vegetation; 'sparsely vegetated': small patches of short sea grasses and/or algae, substrate clearly visible through vegetation; 'moderately vegetated': large patches of sea grasses/algae, substrate partially visible through vegetation; 'densely vegetated': extensive meadows of sea grasses/algae, tall sea grass, substrate not visible through vegetation).

We also recorded the number of potential lobster predators observed in and around each casita. Only 
those predatory species that have been observed attacking Panulirus argus lobsters or containing remnants of lobsters in their guts were considered as predators. These included all nurse sharks Ginglymostoma cirratum, southern stingrays Dasyatis americana, yellow stingrays Urobatis jamaicensis, and green moray eels Gymnothorax funebris, but only those snappers (Lutjanidae), groupers (Serranidae), and invasive lionfish Pterois volitans sufficiently large as to be able to consume juvenile lobsters (i.e. $\geq 20 \mathrm{~cm}$ total length; Eggleston et al. 1997). Other predators included octopuses Octopus vulgaris, loggerhead turtles Caretta caretta, hawksbill turtles Eretmochelys imbricata, large stone crabs Menippe mercenaria, and portunid crabs Portunus spp. and Callinectes spp. (Randall 1967, Eggleston et al. 1990, 1997, Smith \& Herrnkind 1992, Mintz et al. 1994, Arce et al. 1997, Sosa-Cordero et al. 1998, Weiss et al. 2006, 2008). Although purplemouth morays Gymnothorax vicinus and spotted morays, G. moringa were quite abundant in casitas, these morays were not considered as predators because they do not tend to consume $P$. argus lobsters (Lozano-Álvarez \& Spanier 1997, LozanoÁlvarez et al. 2010). Also abundant in casitas were juvenile grunts (Haemulidae) that were too small to consume lobsters (Mintz et al. 1994).

\section{Statistical analyses}

Habitat features and predation risk

We compared the mean depth of casitas between zones with a 1-way ANOVA and computed the percentages of casitas in each zone that were situated on each type and subtype of bottom. For each zone, we computed 2 'predator indices'. Predator index 1 was computed as the total number of predators over the total number of casitas (Mintz et al. 1994). Predator index 2 was computed as the ratio of casitas having predators to the total number of casitas (Sosa-Cordero et al. 1998). We then compared each predator index between zones with a $\chi^{2}$ test for proportions, followed by a multiple comparison test for angular-transformed proportions $(\alpha=0.05)$ (Zar 1999).

Disease prevalence in lobsters

We used 1-way ANOVAs followed by post hoc Tukey's HSD tests for unequal sample sizes $(\alpha=0.05)$ to test the effect of zone on (1) the mean size of all casita-dwelling lobsters and (2) the mean size of dis- eased lobsters only. We used logistic regression analyses to test the effects of size (continuous covariate) and zone (categorical factor) on the probability of finding diseased individuals over the full size range of lobsters. However, given the different size composition of lobsters in each zone (see 'Results'), we also tested the effects of size and zone on the probability of finding diseased individuals within each of the 4 size-related 'benthic phases' of Panulirus argus: small juveniles ( $\leq 30 \mathrm{~mm} \mathrm{CL}$ ), large juveniles (30.1-50 mm CL), subadults (50.1-80 $\mathrm{mm} \mathrm{CL),}$ and adults (>80 mm CL). In all cases, 95\% confidence intervals for prevalence were computed using the score method with continuity correction (Newcombe 1998).

Casita occupancy patterns as related to level of disease prevalence

Disease prevalence in different sampling seasons varied from 0 to $2.9 \%$ in Vigía Chico, from 5.3 to $7.3 \%$ in Los Cayos, and from 5.5 to $11.1 \%$ in Punta Allen (see Candia-Zulbarán et al. 2012). To examine casita occupancy patterns as related to these levels of disease prevalence, we categorized the casitas sampled at each zone and season into 4 groups: Group 0 (empty), Group ND (occupied exclusively by nondiseased lobsters), Group D (occupied exclusively by diseased lobsters), and Group ND+D (co-occupied by non-diseased and diseased lobsters). We then separately tested for a correlation between the level of disease prevalence and the corresponding percentages of each group of casitas with Pearson correlation analyses. We expected the percentages of Group ND to decrease with increasing levels of disease prevalence. However, if more non-diseased lobsters were opting to avoid sharing casitas than to share casitas with diseased conspecifics, then the percentages of Group D should increase more steeply with level of disease prevalence than the percentages of Group ND+D. But if more non-diseased lobsters were opting to share than to avoid sharing casitas with diseased conspecifics, then Group ND+D should increase more steeply with level of disease prevalence than Group D.

Distribution of lobsters among casitas in the presence/absence of diseased conspecifics

Even if cohabitation between non-diseased and diseased lobsters was relatively high, lobsters might 
still exhibit different patterns of distribution and aggregation in the presence versus absence of diseased conspecifics in casitas. To examine this issue, we used 2 different statistical approaches based on the negative binomial distribution (NegBD) of the count frequency of lobsters in casitas: a model selection approach (White \& Eberhardt 1980, White \& Bennets 1996), and Lloyd's indices of 'mean crowding' and 'patchiness' (Lloyd 1967). For these purposes, we recategorized the casitas from each zone into 2 samples: those occupied exclusively by nondiseased lobsters ('ND casitas') and those co-occupied by non-diseased and diseased lobsters ('ND+D casitas'), with the following modifications: for the $\mathrm{ND}+\mathrm{D}$ casita sample, the frequency of casitas with 1 lobster was the number of casitas containing 1 diseased lobster (as opposed to the frequency of casitas with 1 non-diseased lobster for the ND casita sample). Also, as there were only so many empty casitas on a given zone, the frequency of casitas with 0 lobsters was the same for both casita samples.

We separately fitted the NegBD to the count frequency of lobsters in the ND casitas and in the ND+D casitas from each zone using a maximum likelihood procedure (Bliss \& Fisher 1953). The NegBD is described by 2 parameters: $m$, the arithmetic mean (i.e. the mean density of lobsters per casita) and $k$, a dispersion parameter (Fisher 1941). Parameter $k$ allows the NegBD flexibility to handle a wide variety of spatial patterns of organisms because as $k \rightarrow \infty$, the distribution approaches a Poisson (random) distribution and the data can be modeled as a Poisson process, whereas as $k \rightarrow 0$, the distribution becomes more clumped and the data can be modeled with overdispersion (Anscombe 1950, Bliss \& Fisher 1953, White \& Bennets 1996).

Model selection. Model selection is an analytical approach based on information theory that uses a likelihood ratio testing framework to contrast a set of competing models (representing multiple working hypotheses) for a given set of samples (Burnham \& Anderson 2002). White \& Eberhardt (1980) developed a set of 4 models to contrast parameters of the NegBD for a set of samples $v$. The general (most parameterized) model, $\left\{k_{V}, m_{V}\right\}$, predicts that all samples differ in $m$ and $k$. Then, 3 models with fewer parameters are compared with the general model. These models are $\left\{k, m_{v}\right\}$ : samples have a common $k$ but different $m_{i}\left\{k_{V \prime}, m\right\}$ : samples have a different $k$ but a common $m$, and $\{k, m\}$ : samples have a common $k$ and a common $m$ (the reduced model). This set of models has proved useful to compare the NegBD for a set of samples over time (e.g. White \& Eberhardt 1980, Briones-Fourzán et al. 2012) or among habitats (e.g. White \& Bennets 1996, Kinlaw 2006).

The best approximating model would be that with the lowest Akaike information criterion corrected for sample size (AICc, see Burnham \& Anderson 2002), but other criteria associated with the AICc provide better measures of the strength of evidence for each model. These criteria are the delta AICC $\left(\Delta_{i}\right)$, the Akaike weight $\left(w_{i}\right)$, the relative likelihood of each model $\left(l_{i}\right)$ and the evidence ratios. $\Delta_{i}$ is the AICc of a given model minus the AICc of the best model (whose $\Delta_{i}$ is set to zero), whereas $w_{i}$ represents the ratio of the $\Delta_{i}$ of a given model relative to the whole set of models (the $w_{i}$ from all models sum to 1 ) and thus represents the probability of each model given the data. The $l_{i}$ for each model is computed as $\mathrm{e}^{-\left(\Delta_{i} / 2\right)}$. Evidence ratios are computed as the ratios of either $W_{i}$ or $l_{i}$ for any 2 models (Burnham et al. 2011). Values of $w_{i}$ also provide a basis for model averaging, a procedure that allows the entire set of models to be used to compute a weighted average for each parameter and its corresponding unconditional variance. Because model averaging incorporates model uncertainty, it allows for multi-model inference, in particular when more than 1 model can explain the data well (Burnham \& Anderson 2002, Johnson \& Omland 2004, Hobbs \& Hillborn 2006).

We used the software EcoMeth 6.1 (Kenney \& Krebs 2002), which includes a modification of the computer program originally developed by White \& Bennets (1996), to contrast the set of 4 models for our set of 2 casita samples (ND and ND+D) from each zone. The output data from this software includes, for each model, the maximum likelihood, the AIC, a test for goodness of fit to the NegBD, and the corresponding estimates of $m$ and $k$ with their respective variances. Using these data, we computed the AICc, $\Delta_{i}$ $W_{i}$ and $l_{i}$ for each model and performed model averaging (for equations and procedures see Burnham \& Anderson 2002, Hobbs \& Hillborn 2006).

Lloyd's mean crowding and patchiness. Using the maximum likelihood estimates of $m$ and $k$ (and their respective variances) from the general model $\left\{k_{V \prime}\right.$ $\left.m_{v}\right\}$, we computed Lloyd's indices of 'mean crowding' $\left(m^{*}\right)$ and 'patchiness' $\left(m^{*} / m\right)$ (Lloyd 1967) for the 2 casita samples from each zone. Mean crowding, estimated as $m^{*}=m+(m / k)$, is the mean number per individual of other individuals in the same casita and has the important property of not being affected by empty sampling units (Lloyd 1967, Bez 2000). However, patchiness (the ratio of mean crowding to mean density) is a more useful measure 
of aggregation because it measures how many times as crowded an individual is, on average, as it would be if the same population had a random (Poisson) distribution. Patchiness is estimated as $m^{*} / m=1+$ $(1 / k)$, where $1 / k$ is that proportion by which mean crowding exceeds mean density, thus providing a meaningful ecological interpretation to parameter $k$ (Lloyd 1967) because values of patchiness equal to 1 are representative of Poisson distributions and values of patchiness larger than 1 are representative of over-dispersed distributions (Hurlbert 1990, Bez 2000). Standard errors for mean crowding and patchiness were estimated with the equations provided by Lloyd (1967) and used to construct 95\% confidence intervals.

Table 1. Panulirus argus. Summary of data from lobsters sampled from casitas distributed over 3 zones in Bahía de la Ascensión (all sampling seasons combined). CL is mean $( \pm \mathrm{SD})$ carapace length $(\mathrm{mm})$. 'Diseased lobsters' are visibly infected with PaV1. Down each column, data with different superscript letters are significantly different $(\alpha=0.05)$

\begin{tabular}{|lccccc|}
\hline \multirow{2}{*}{ Bay zone } & \multicolumn{2}{c}{ All lobsters } & \multicolumn{3}{c|}{ Diseased lobsters } \\
\cline { 3 - 6 } & $\mathrm{n}$ & $\mathrm{CL}$ & $\mathrm{n}$ & $\mathrm{CL}$ & $\begin{array}{c}\text { Prevalence (\%) } \\
(95 \% \mathrm{CI})\end{array}$ \\
\hline Punta Allen & 1842 & $49.8 \pm 18.6^{\mathrm{a}}$ & 155 & $39.0 \pm 11.5^{\mathrm{a}}$ & $8.4(7.2-9.7)^{\mathrm{a}}$ \\
Los Cayos & 991 & $54.3 \pm 14.9^{\mathrm{b}}$ & 61 & $41.4 \pm 10.6^{\mathrm{a}}$ & $6.2(4.7-7.9)^{\mathrm{b}}$ \\
Vigía Chico & 2016 & $58.1 \pm 16.2^{\mathrm{c}}$ & 31 & $37.5 \pm 13.0^{\mathrm{a}}$ & $1.5(0.4-4.3)^{\mathrm{c}}$ \\
Total & 4849 & & 247 & & \\
\hline
\end{tabular}

Table 2. Panulirus argus. Estimates for logistic regression analyses testing the effects of size (carapace length, CL, mm) and zone (reference level: Los Cayos) on the probability of finding diseased lobsters across the full size range (all lobsters: 9.5-115.2 $\mathrm{mm} \mathrm{CL}$ ) and within each of 3 benthic phases (small juveniles: $\leq 30 \mathrm{~mm} \mathrm{CL}$; large juveniles: $30.1-50 \mathrm{~mm} \mathrm{CL}$; and sub-adults: 50.1$80 \mathrm{~mm} \mathrm{CL}$ ). No diseased adults (>80 mm CL) occurred in any zone. In all cases, interaction effects (not shown) were not significant

\begin{tabular}{|lrrrrrr|}
\hline Effect & Estimate & SE & $\begin{array}{c}\text { Wald } \\
\text { statistic }\end{array}$ & df & $p$ & $\begin{array}{c}\text { Odds ratio } \\
(95 \% \text { CI })\end{array}$ \\
\hline All lobsters & & & & & & \\
Size & -0.050 & 0.004 & 126.137 & 1 & $<0.001$ & $0.95(0.94-0.96)$ \\
Vigía Chico & -0.899 & 0.133 & 45.633 & 1 & $<0.001$ & $0.41(0.31-0.53)$ \\
Punta Allen & 0.462 & 0.097 & 22.589 & 1 & $<0.001$ & $1.59(1.31-1.92)$ \\
Small juveniles & & & & & & \\
Size & 0.021 & 0.034 & 0.368 & 1 & 0.544 & $1.02(0.95-1.09)$ \\
Vigía Chico & -0.464 & 0.294 & 2.503 & 1 & 0.114 & $0.63(0.35-1.12)$ \\
Punta Allen & 0.080 & 0.212 & 0.142 & 1 & 0.706 & $1.08(0.71-1.64)$ \\
Large juveniles & & & & & & \\
Size & -0.039 & 0.015 & 6.393 & 1 & 0.011 & $0.96(0.93-0.99)$ \\
Vigía Chico & -0.866 & 0.171 & 25.763 & 1 & $<0.001$ & $0.42(0.30-0.59)$ \\
Punta Allen & 0.514 & 0.122 & 17.618 & 1 & $<0.001$ & $1.67(1.32-2.13)$ \\
Sub-adults & & & & & & \\
Size & -0.132 & 0.026 & 26.616 & 1 & $<0.001$ & $0.88(0.83-0.92)$ \\
Vigía Chico & -1.301 & 0.321 & 16.451 & 1 & $<0.001$ & $0.27(0.15-0.51)$ \\
Punta Allen & 0.812 & 0.225 & 13.074 & 1 & $<0.001$ & $2.25(1.45-3.50)$ \\
\hline
\end{tabular}

\section{RESULTS}

\section{Lobster samples and disease prevalence}

In total, we sampled 531 casitas (234 in Punta Allen, 138 in Los Cayos, and 159 in Vigía Chico) yielding a total sample of 4849 lobsters (size range: 5-115.2 $\mathrm{mm}$ CL). The mean size of all lobsters = 115.909, $\mathrm{p}<0.001)$, increasing from Punta the mean size of diseased lobsters (size range: with zone $\left(F_{1,244}=1.427, \mathrm{p}=0.242\right)$ (Table 1$)$, with an average value of $39.4 \pm 11.4($ mean $\pm \mathrm{SD})$.

Overall disease prevalence ranged from $1.5 \%$ in Vigía Chico to $8.4 \%$ in Punta Allen (Table 1). Thus, across the full size range of lobsters, the probability of finding diseased lobsters decreased with increasing lobster size and differed significantly with zone (Table 2). Relative to Los Cayos (reference zone), the probability of finding diseased lobsters was significantly lower in Vigía Chico (odds ratio: 0.41) and higher in Punta Allen (odds ratio: 1.59) (Table 2). Large juveniles and sub-adults were the most abundant occupants of casitas followed by small juveniles and adults, but the 4 benthic phases occurred in different proportions at each zone (Fig. 2a). Because we found no visibly diseased adults in any zone (Fig. 2b), we only tested the effects of size and zone on the probability of finding diseased individuals within each of the other 3 benthic phases. Neither effect was significant for small juveniles (Table 2), but we suspect that the nonsignificant effect of zone was due to the limited samples of small juveniles from Los Cayos and Vigía Chico, which resulted in very wide confidence intervals (Fig. 2b). By contrast, for large juveniles and sub-adults, the probability of finding diseased individuals decreased with increasing size of lobsters and, relative to Los Cayos, was significantly lower in Vigía Chico (odds ratios: 0.42 and 0.27 , respectively) and higher in Punta Allen (odd ratios: 1.76 and 2.25, respectively) (Table 2, Fig. 2b). 

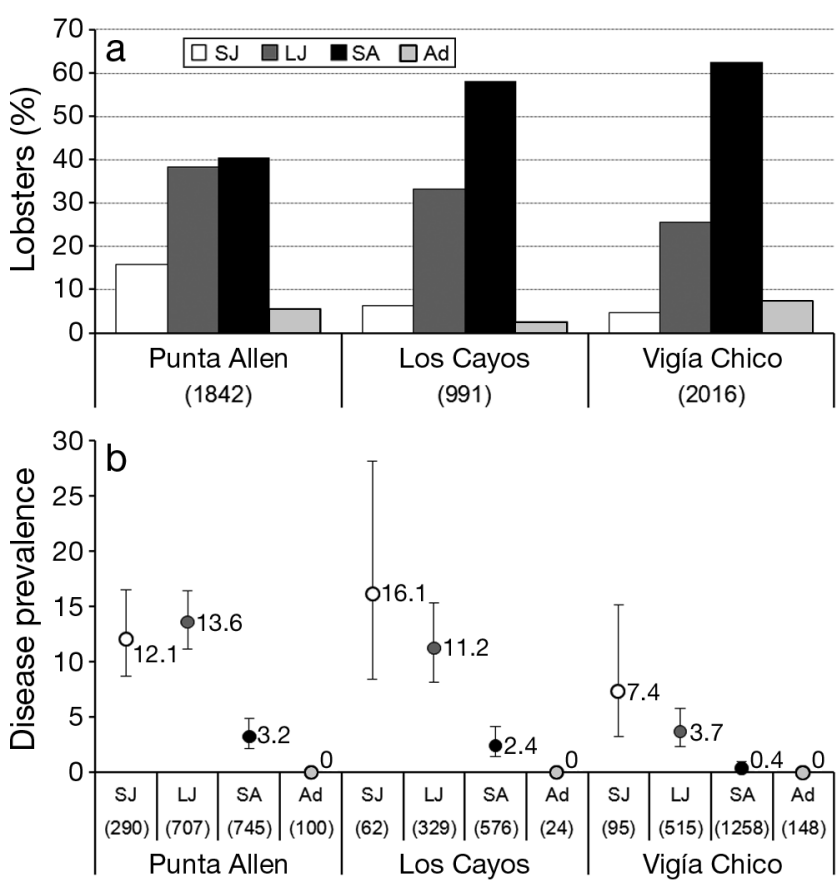

Bay Zone

Fig. 2. Panulirus argus. (a) Percentages of lobsters categorized into 4 benthic phases: small juveniles (SJ: $<30 \mathrm{~mm}$ carapace length, CL), large juveniles (LJ: 30.1-50 mm CL), subadults (SA: 50.1-80 mm CL), and adults (Ad: $>80 \mathrm{~mm}$ CL) occupying casitas distributed in 3 zones of Bahía de la Ascensión, and (b) disease prevalence (\% lobsters visibly infected with PaV1) in each benthic phase. Numbers in parentheses along $x$-axis are sample sizes. Numbers on graph are means and error bars are $95 \%$ confidence intervals

\section{Habitat features and predation risk}

The mean $( \pm 95 \% \mathrm{CI})$ depth at which casitas were situated differed significantly with zone $\left(F_{2,525}=\right.$ 64.582, p < 0.001), being much shallower in Vigía Chico $(1.5 \pm 0.14 \mathrm{~m}$; range: $0.8-2.4 \mathrm{~m})$ than in Punta Allen $(2.5 \pm 0.15 \mathrm{~m}$; range: $0.9-5.5 \mathrm{~m})$ and Los Cayos (2.4 $\pm 0.17 \mathrm{~m}$; range: 0.8-4.2 m). In Punta Allen, $93 \%$ casitas were situated on soft bottoms, mostly densely $(40.3 \%)$ or moderately vegetated (35.2\%) (Fig. 3). In Los Cayos, $96 \%$ casitas were situated on soft bottoms, mostly moderately (57.3\%) and densely vegetated (23.4\%) (Fig. 3). In Vigía Chico, by contrast, 64 \% casitas were situated on bare or sparsely vegetated hard bottoms, $30 \%$ on bare or sparsely vegetated soft bottoms, and only $6 \%$ on moderately or densely vegetated soft bottoms (Fig. 3). The predator guild was similar in all zones (Table 3 ), but the 2 predator indices differed significantly with zone (predator index 1: $\chi^{2}=115.696, \mathrm{df}=2, \mathrm{p}<0.001$; predator index $2: \chi^{2}=$ 44.376, $\mathrm{df}=2, \mathrm{p}<0.001)$. Predator index 1 was significantly higher in Los Cayos than in Punta Allen and Vigía Chico (Table 3), whereas predator index 2

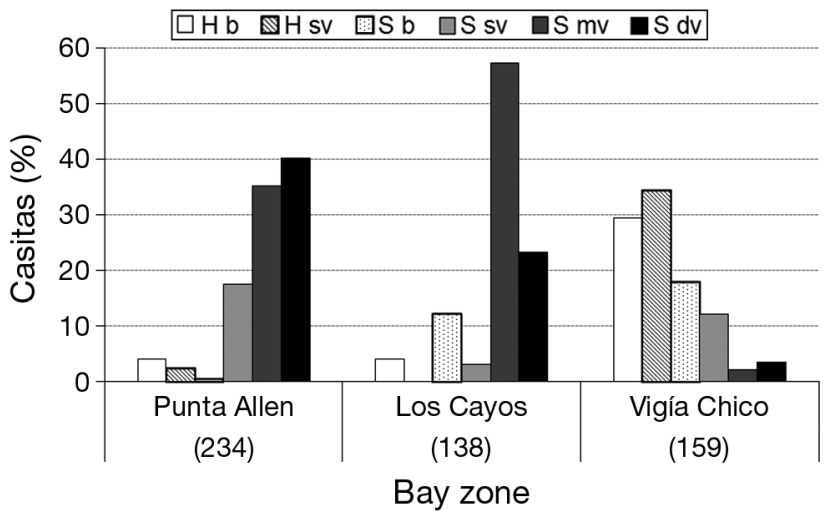

Fig. 3. Percentages of casitas at each bay zone that were situated on hard $(\mathrm{H})$ or soft $(\mathrm{S})$ bottoms with different degrees of vegetation (b: bare; sv: sparsely vegetated; mv: moderately vegetated; $d v$ : densely vegetated). Numbers in parentheses are sample sizes

showed a significant decreasing trend from Los Cayos to Punta Allen to Vigía Chico (Table 3).

\section{Casita occupancy patterns as related to disease prevalence}

Table 4 provides the levels of disease prevalence for each zone and sampling season (see Candia-Zulbarán

Table 3. Lobster predators recorded in and around casitas at each bay zone. For each index, different superscript letters indicate significantly different values. (Nurse sharks: Gynglimostoma cirratum; stingrays: Dasyatis americana and Urobatis jamaicencis; green morays: Gymnothorax funebris; lionfish: Pterois volitans; snappers: Lutjanus spp., groupers: Epinephelus spp. and Mycteroperca sp.; octopuses: Octopus vulgaris; sea turtles: Caretta caretta, Eretmochelys imbricata; stone crabs: Menippe mercenaria; portunid crabs: Portunus spp. and Callinectes spp.)

\begin{tabular}{|lccc|}
\hline Type of predator & $\begin{array}{c}\text { Punta } \\
\text { Allen }\end{array}$ & $\begin{array}{c}\text { Los } \\
\text { Cayos }\end{array}$ & $\begin{array}{c}\text { Vigía } \\
\text { Chico }\end{array}$ \\
\hline Nurse sharks & 6 & 11 & 4 \\
Stingrays & 5 & 8 & 1 \\
Green morays & 6 & 0 & 7 \\
Lionfish & 5 & 2 & 0 \\
Snappers & 2 & 3 & 3 \\
Groupers & 0 & 2 & 0 \\
Octopuses & 0 & 1 & 0 \\
Sea turtles & 3 & 0 & 1 \\
Stone crabs & 40 & 57 & 30 \\
Portunid crabs & 27 & 45 & 19 \\
Total no. of predators (A) & 94 & 129 & 65 \\
Total no. of casitas (B) & 234 & 138 & 159 \\
No. of casitas with predators (C) & 76 & 86 & 44 \\
Predator index 1 (A/B) & $0.402^{\mathrm{b}}$ & $0.935^{\mathrm{a}}$ & $0.409^{\mathrm{b}}$ \\
Predator index 2 (C/B) & $0.325^{\mathrm{b}}$ & $0.623^{\mathrm{a}}$ & $0.277^{\mathrm{c}}$ \\
\hline
\end{tabular}


et al. 2012) and the corresponding numbers of Group 0 casitas (empty), Group ND casitas (occupied exclusively by non-diseased lobsters), Group D casitas (occupied exclusively by diseased lobsters), and Group ND+D casitas (co-occupied by non-diseased + diseased lobsters). The correlations for disease prevalence versus the percentages of each group of casitas $(\mathrm{N}=10$ data points in all cases) were, respectively, Group 0 not significant $(\mathrm{r}=$ $0.170, p=0.639$ ), Group ND negative and significant $(\mathrm{r}=-0.948, \mathrm{p}<0.001)$, Group D positive and significant $(r=0.636, p=0.048)$, and Group ND+D positive and significant $(\mathrm{r}=0.954, \mathrm{p}<$ 0.001) (Fig. 4). However, Group ND+D increased more steeply with disease prevalence than Group D (Fig. 4), indicating that, with higher levels of disease prevalence, many more non-diseased lobsters opted to share than to not share casitas with diseased conspecifics.

In general, most casitas harbored exclusively nondiseased lobsters, many were co-occupied by non-diseased + diseased lobsters, few were empty, and even less harbored exclusively diseased lobsters (Table 4). However, the percentages of the 4 groups of casitas differed significantly between the 3 zones $\left(\chi^{2}=\right.$ $49.448, \mathrm{df}=6, \mathrm{p}<0.001)$, but not between Punta Allen and Los Cayos $\left(\chi^{2}=1.654, \mathrm{df}=3, \mathrm{p}=0.647\right.$ ) (Table 4). All 3 zones had similar percentages of empty casitas, but Vigía Chico had proportionally more casitas with non-diseased lobsters and less casitas with diseased lobsters and with non-diseased + diseased lobsters than Punta Allen and Los Cayos (Table 4). Of the 31 casitas occupied by diseased lobsters, 22 harbored a single individual, 7 harbored 2 individuals, and 2 harbored 3 individuals. Of the total 247 diseased lobsters, $16.7 \%$ were not cohabiting with non-diseased conspecifics. However, solitary occupation of casitas was observed for $8.9 \%$ of all diseased lobsters compared to $1.1 \%$ of all non-diseased lobsters.

\section{Distribution of lobsters among casitas in the presence/absence of diseased conspecifics}

The distribution of lobsters among ND and ND+D casitas in each zone is shown in Fig. 5. In all cases the NegBD fitted the data well (range in p-values: 0.2030.930 ), although the frequency of both ND and ND+D

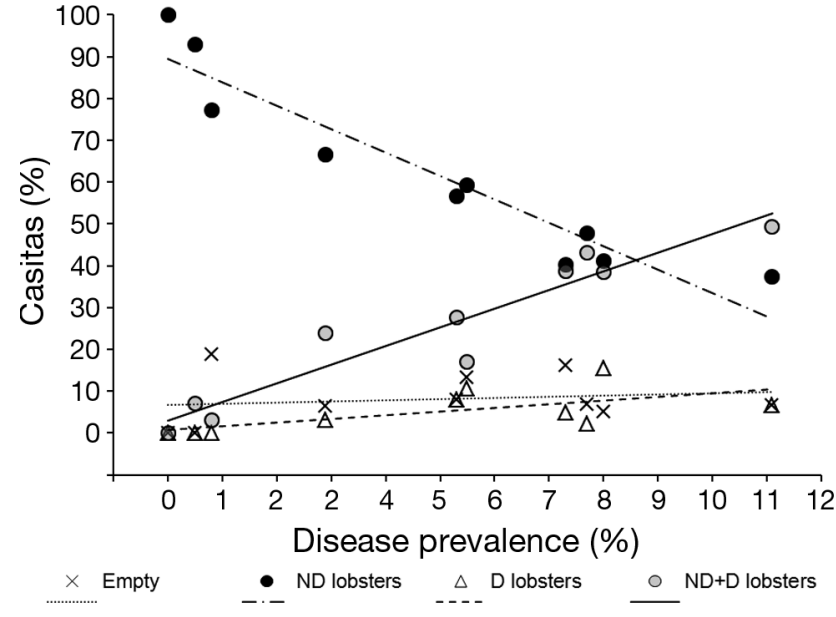

Fig. 4. Panulirus argus. Correlation between the levels of disease prevalence (\% lobsters visibly infected with PaV1) in different zones and sampling seasons and the corresponding percentages of empty casitas, casitas occupied exclusively by non-diseased (ND) lobsters or by diseased (D) lobsters, and casitas co-occupied by non-diseased + diseased $(\mathrm{ND}+\mathrm{D})$ lobsters. The values of all variables appear in Table 4 . The trend lines are only indicative

casitas with $>30$ lobsters was higher in Vigía Chico (Fig. 5c) than in Punta Allen and Los Cayos (Fig. 5a,b). In ND+D casitas, the range in number of non-diseased lobsters was 1-42 in Punta Allen (median, interquartile range: $5,2-9), 1-38$ in Los Cayos $(4,2-11)$, and 1-75 in Vigía Chico $(7,2.5-24)$, whereas the range in number of diseased lobsters 

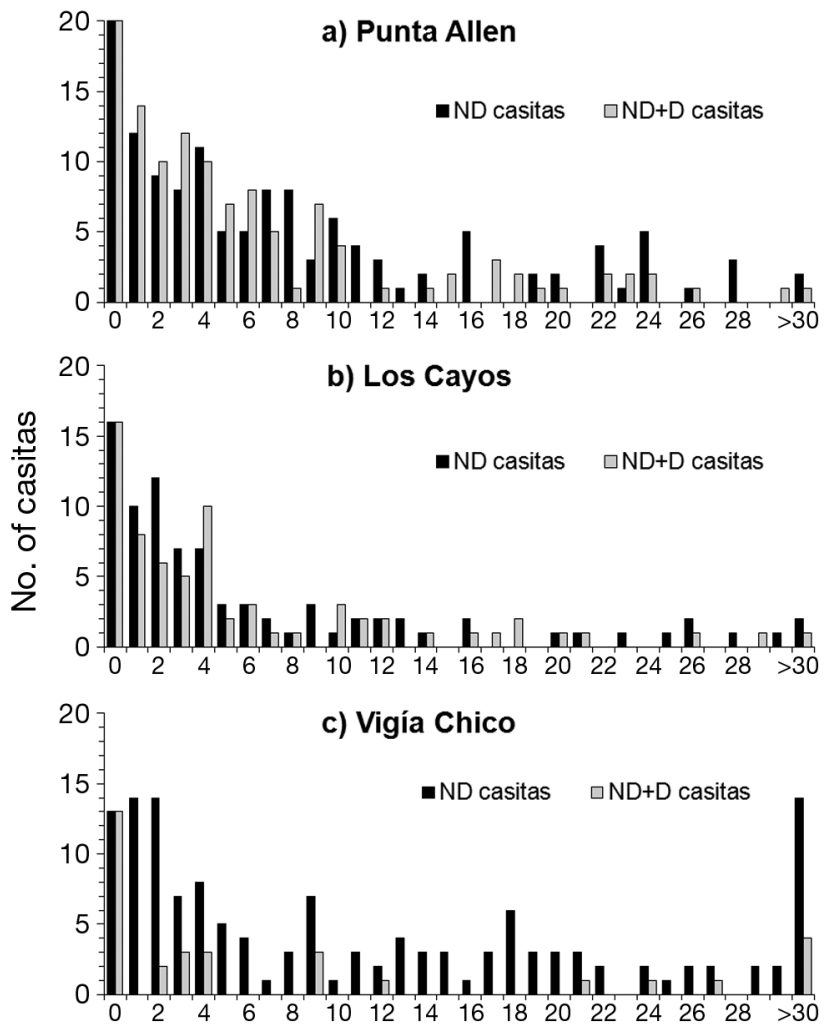

No. of lobsters in casita

Fig. 5. Panulirus argus. Distribution of lobsters among casitas occupied exclusively by non-diseased lobsters (ND casitas) and among casitas co-occupied by non-diseased and diseased lobsters (ND+D casitas) in (a) Punta Allen, (b) Los Cayos, and (c) Vigía Chico
Cayos, the weighted average values of $m$ (Fig. 6a) and $k$ (Fig. 6b) did not differ meaningfully between ND and ND+D casitas. For Vigía Chico, by contrast, the average values of $m$ were similar between ND and ND+D casitas (Fig. 6a), but the average value of $k$ was substantially lower (reflecting a more clumped distribution) for ND+D casitas than for ND casitas (Fig. 6b).

\section{Lloyd's mean crowding and patchiness}

Mean crowding of lobsters was similar for ND and ND+D casitas in Punta Allen and also in Los Cayos, indicating that, in these zones, there were between 14.4 and 18.3 lobsters per individual lobster per casita irrespective of the presence of diseased conspecifics (Fig. 7a). In Vigía Chico, by contrast, there were 27.3 and 44.4 lobsters per individual lobster in ND and ND+D casitas, respectively, but with a wide confidence interval for the latter value (Fig. 7a). Patchiness was virtually identical for ND casitas and for ND+D casitas in Punta Allen (2.2 in both cases) as well as in Los Cayos (2.6 in both cases) (Fig. 7b), indicating that, irrespective of the presence of diseased conspecifics in casitas, lobsters in these zones were 2 to 3 times as crowded as they would be if they had been randomly distributed among casitas. In Vigía Chico, by contrast, patchiness differed considerably between ND casitas (2.2) and ND+D casitas (4.6) and was $1-7$ in Punta Allen $(1,1-2)$ and 1-4 in both Los Cayos $(1,1-1)$ and Vigía Chico (1, 1-1.5). Therefore, most ND+D casitas contained only 1 or 2 diseased lobsters. However, 1 casita in Punta Allen contained 7 diseased +10 non-diseased lobsters and another contained 4 diseased + 19 non-diseased lobsters, while in Vigía Chico 1 casita harbored 4 diseased + 5 non-diseased lobsters.

\section{Model selection and averaging}

At least 2 models (not necessarily the same) explained the data from each zone well (Table 5), indicating substantial model uncertainty (quantified by the model probabilities); therefore, we proceeded with model averaging. For Punta Allen and Los
Table 5. Panulirus argus. Results of model selection contrasting a set of 4 models (based on parameters of the negative binomial distribution) for a set of $2 \mathrm{ca}$ sita samples $V$ (casitas occupied exclusively by non-diseased lobsters and casitas co-occupied by non-diseased and diseased lobsters) from each bay zone $\left(\Delta_{i}\right.$ : delta $\mathrm{AICC} ; w_{i}$ : Akaike weight; $l_{i}$ : model likelihood; evidence ratio: the ratio of the $l_{i}$ of the best model to the $l_{i}$ of each of the other models)

\begin{tabular}{|c|c|c|c|c|c|c|c|}
\hline Model & $\begin{array}{l}\text { No. of } \\
\text { param. }\end{array}$ & $\begin{array}{l}\text { Log- } \\
\text { likelihood }\end{array}$ & $\mathrm{AICc}$ & $\Delta_{i}$ & $W_{i}$ & $l_{i}$ & $\begin{array}{l}\text { Evidence } \\
\text { ratio }\end{array}$ \\
\hline \multicolumn{8}{|c|}{ Punta Allen } \\
\hline$\left\{k, m_{V}\right\}$ & 3 & -752.666 & 1511.431 & 0 & 0.448 & 1.000 & \\
\hline$\{k, m\}$ & 2 & -754.141 & 1512.331 & 0.900 & 0.286 & 0.638 & 1.6 \\
\hline$\left\{k_{V \prime}, m_{V}\right\}$ & 4 & -752.653 & 1513.472 & 2.041 & 0.162 & 0.360 & 2.8 \\
\hline$\left\{k_{V}, m\right\}$ & 3 & -754.123 & 1514.345 & 2.914 & 0.104 & 0.233 & 4.3 \\
\hline \multicolumn{8}{|c|}{ Los Cayos } \\
\hline$\{k, m\}$ & 2 & -442.839 & 889.758 & 0 & 0.515 & 1.000 & \\
\hline$\left\{k, m_{V}\right\}$ & 3 & -442.629 & 891.419 & 1.661 & 0.225 & 0.436 & 2.3 \\
\hline$\left\{k_{V}, m\right\}$ & 3 & -442.839 & 891.839 & 2.081 & 0.182 & 0.353 & 4.3 \\
\hline$\left\{k_{V}, m_{V}\right\}$ & 4 & -442.626 & 893.528 & 3.770 & 0.078 & 0.152 & 6.6 \\
\hline \multicolumn{8}{|c|}{ Vigía Chico } \\
\hline$\left\{k_{V^{\prime}} m\right\}$ & 3 & -575.815 & 1157.776 & 0 & 0.712 & 1.000 & \\
\hline$\left\{k_{V}, m_{V}\right\}$ & 4 & -575.681 & 1159.607 & 1.831 & 0.285 & 0.400 & 2.5 \\
\hline$\{k, m\}$ & 2 & -582.888 & 1169.849 & 12.072 & 0.002 & 0.002 & 500.4 \\
\hline$\left\{k, m_{V}\right\}$ & 3 & -582.609 & 1171.364 & 13.558 & 0.001 & 0.001 & 1073.8 \\
\hline
\end{tabular}



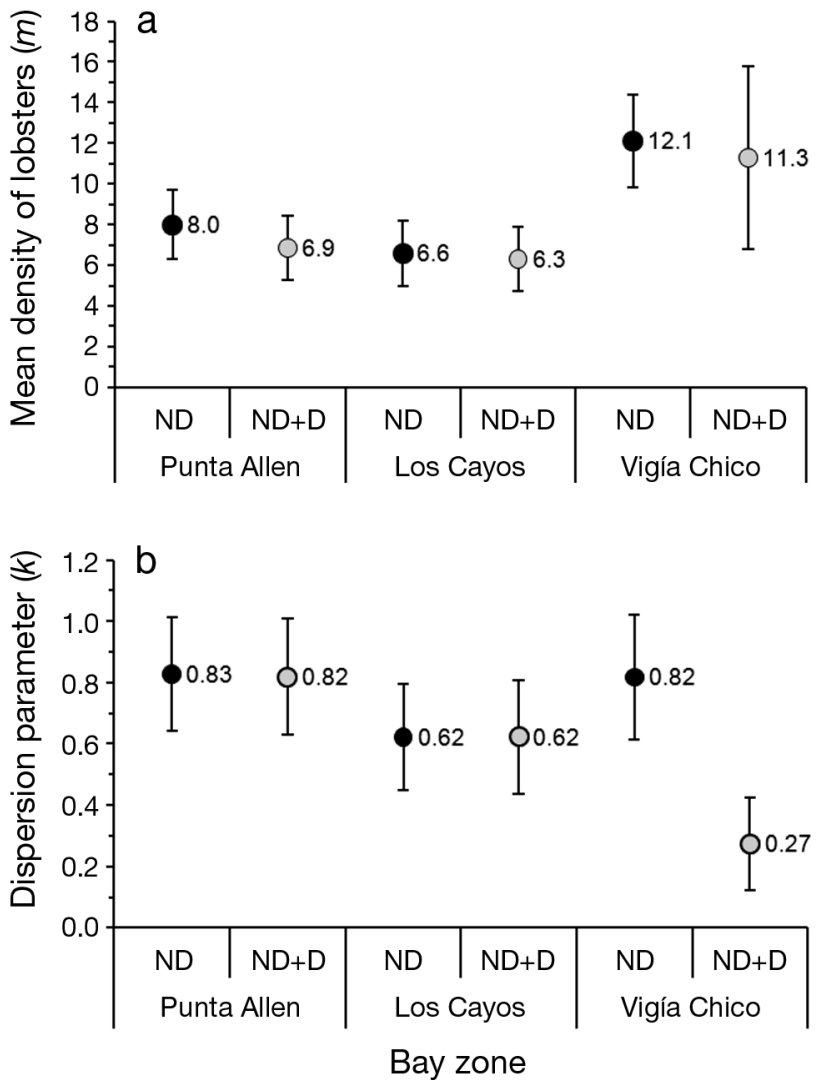

Fig. 6. Panulirus argus. Weighted average values of (a) $m$ (mean density of lobsters per casita) and (b) $k$ (dispersion parameter of the negative binomial distribution) for lobsters distributed among casitas occupied exclusively by nondiseased lobsters (ND casitas) and among casitas cooccupied by non-diseased and diseased lobsters (ND+D casitas) at each bay zone. Numbers on graph are weighted averages and error bars are $95 \%$ confidence intervals

the confidence intervals for these values did not overlap (Fig. 7b), indicating that, in this zone, lobsters were actually more crowded in casitas where diseased conspecifics were present. Indeed, the casita with the most lobsters was a casita from Vigía Chico harboring 75 non-diseased lobsters (size range 12.8-89.0 $\mathrm{mm} \mathrm{CL}$ ) and 2 diseased lobsters (33.5 and $57.3 \mathrm{~mm} \mathrm{CL}$ ). In no case did the confidence interval for mean patchiness include 1 (Fig. 7b), indicating a rather clumped distribution of lobsters in casitas consistent with the gregarious nature of Panulirus argus.

\section{DISCUSSION}

The present study strongly suggests that, in the casita-enhanced system of Bahía de la Ascensión, avoidance of lobsters with the PaV1 disease by non-
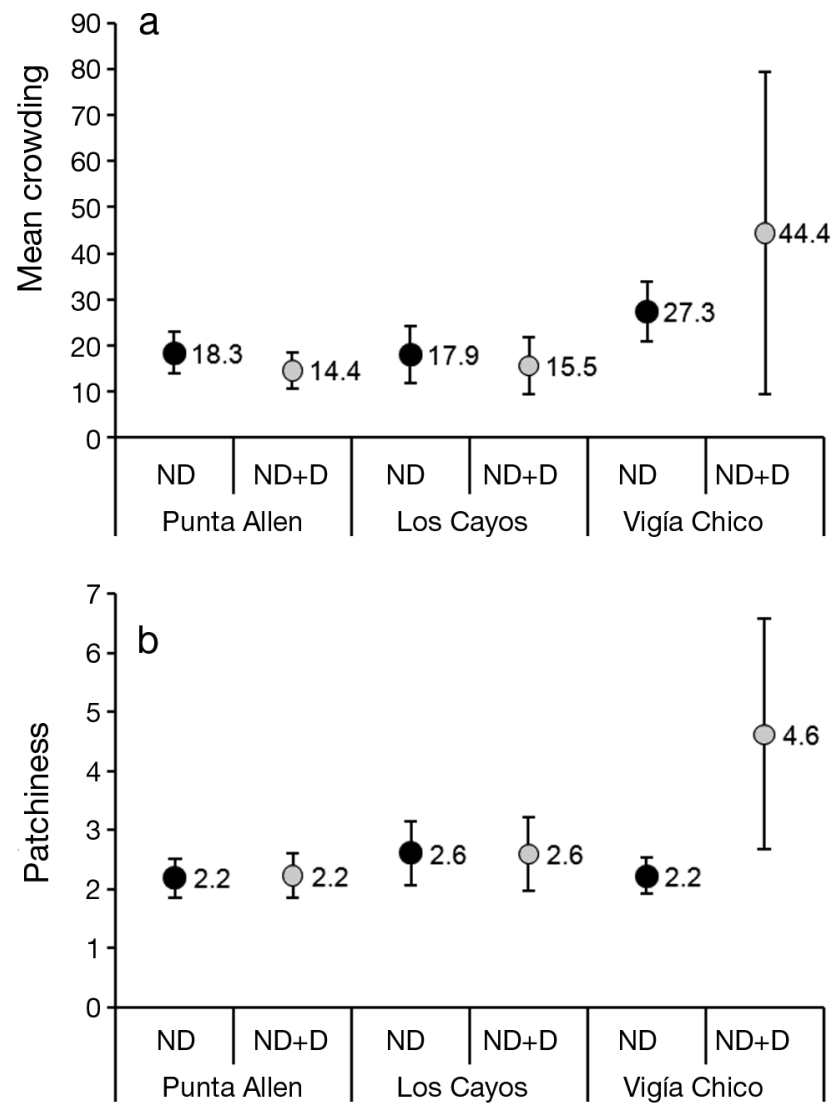

Bay zone

Fig. 7. Panulirus argus. Lloyd's indices of (a) mean crowding and (b) patchiness for lobsters distributed among casitas occupied exclusively by non-diseased lobsters (ND casitas) and among casitas co-occupied by non-diseased and diseased lobsters (ND+D casitas) at each bay zone. Numbers on graph are means and error bars are $95 \%$ confidence intervals

diseased conspecifics is weak at best. That there is some level of disease avoidance is indicated by the solitary occupation of casitas by $8.9 \%$ of all diseased lobsters (compared to $1.1 \%$ of all non-diseased lobsters) and by the increase in the percentages of casitas harboring exclusively diseased lobsters with increasing levels of disease prevalence. However, the percentages of casitas co-occupied by nondiseased and diseased lobsters increased more steeply with increasing disease prevalence despite the presence of empty casitas in all zones at all sampling seasons. Moreover, in Punta Allen and Los Cayos the distribution and aggregation patterns of lobsters were not affected by the presence of diseased conspecifics in casitas, whereas, in Vigía Chico, lobsters were actually more crowded in casitas where diseased conspecifics were present. Despite differences in the overall mean size of lob- 
sters and level of disease prevalence between zones, the mean size of diseased lobsters was similar in all 3 zones but the level of disease prevalence was lower in lobsters of all benthic phases in Vigía Chico.

\section{Habitat features may underlie weak disease avoidance by lobsters in Bahía de la Ascensión}

Our results suggest that, in Bahía de la Ascensión, lobsters strongly depend on casitas for survival and that, in general, investment in disease avoidance does not necessarily pay off for non-diseased lobsters. This may result from an interaction between predation risk and availability of alternative shelters: if the former is high and the latter is low, lobsters may rather cohabit with diseased conspecifics than increase their time of exposure to predators by seeking another shelter (Lozano-Álvarez et al. 2008). In laboratory experiments, non-diseased lobsters significantly avoided shelters harboring a diseased conspecific both in the absence (Behringer et al. 2006) and the presence of predation risk (a caged octopus) (Behringer \& Butler 2010). In these experiments, however, non-diseased lobsters were offered a choice between the shelter containing the diseased conspecific and an identical, readily accessible empty shelter. In Bahía de la Ascensión, by contrast, many lobsters may not have this choice. In Vigía Chico, in particular, there were virtually no structures other than casitas that could provide refuge to lobsters. This was also the general case for the vegetated areas within Punta Allen and Los Cayos, although in these zones some natural shelters (e.g. small isolated coral heads and rocks) occurred in areas nearer to the coral reef habitat. Yet, where casitas are available, lobsters tend to forgo small shelters in favor of casitas (Lozano-Álvarez et al. 2009) because the large refuge area provided by casitas increases the potential for gregariousness and hence the benefit of group defense (Eggleston \& Lipcius 1992, Mintz et al. 1994, Briones-Fourzán et al. 2007). Similarly, in habitats where unusually large natural crevices occur, these crevices typically contain the majority of lobsters (Butler \& Herrnkind 1997).

In experimental casitas deployed on several sites in Florida Bay (Mintz et al. 1994) and the Bahamas (Eggleston et al. 1997), lobster survival was positively correlated with abundance of lobsters in casitas and negatively correlated with abundance of predators in casitas (our predator index 1). In our 3 bay zones, the predator indices that we estimated were within the upper range of those estimated by Mintz et al. (1994, predator index 1) and Sosa-Cordero et al. (1998, predator index 2), suggesting a relatively high risk of predation for lobsters in Bahía de la Ascensión. However, although Los Cayos exhibited the highest predator indices, Vigía Chico exhibited the highest density of lobsters per casita suggesting that, in addition to predation risk, other habitat features may underlie the weak disease avoidance by lobsters in Bahía de la Ascensión.

Our gross assessment of habitat features was based on qualitative observations but generally agrees with the landscape and local distribution of benthic habitats across the bay (Arellano-Méndez et al. 2011). Thus, at Punta Allen and Los Cayos, most casitas were situated on moderately to densely vegetated habitats at an average depth of $2.5 \mathrm{~m}$, whereas, at Vigía Chico, most casitas were situated on bare (whitish calcareous pavement, occasionally with a thin layer of fine sediment) or sparsely vegetated bottoms at an average depth of $1.5 \mathrm{~m}$. Spiny lobsters prefer dark shelters (Spanier \& Zimmer-Faust 1988, Gristina et al. 2009) because they are quite sensitive to intense sunlight (Meyer-Rochow 1994), and the low-lying casitas - which are also called 'sombras' (i.e. 'shades') for good reason - considerably reduce sunlight due to their flat shape and large area/height ratio. For example, at 12:00 $\mathrm{h}$, the amount of light reaching the inner center of casitas deployed in exposed seawater tanks (1 $\mathrm{m}$ in depth) was $1.25 \%$ of the surface irridiance, and $4.7 \%$ of the irridiance at the unshaded tank floor (Lozano-Álvarez \& BrionesFourzán 2001).

However, in sea grass habitats, the amount of sunlight reaching the bottom decreases with increasing depth and canopy morphology (i.e. leaf area, leaf biomass, and shoot density) (Enríquez \& PantojaReyes 2005), and hence even modest increases in plant biomass greatly increase protection from visual predators to large juvenile lobsters (Lipcius et al. 1998). Therefore, the extensive presence of vegetation in Punta Allen and Los Cayos probably enhances the protection against predators and intense sunlight afforded to lobsters by casitas. In contrast, casitas probably afford the only protection against both predators and intense sunlight to lobsters on the far less vegetated (and shallower) bottoms of Vigía Chico. In the latter circumstances, investment in disease avoidance may be more costly for lobsters, potentially explaining why lobsters in Vigía Chico tended to be more crowded irrespective of the presence of diseased conspecifics in casitas. 


\section{Sunlight/UV exposure may reduce disease prevalence in Vigía Chico}

In the laboratory, the rate of contact transmission of PaV1 was found to be 5 times as high as the rate of water-borne transmission (Butler et al. 2008). Yet, in our study, the lowest levels of clinical prevalence of PaV1 in all sampling seasons and in all lobster benthic phases occurred in Vigía Chico, where the highest density of lobsters per casita and the highest measures of aggregation in ND+D casitas also occurred. Furthermore, PCR assays to detect PaV1 DNA in lobsters from Bahía de la Ascensión also indicate that the true prevalence of PaV1 (subclinical + clinical) is also significantly lower in all benthic phases of lobsters at Vigía Chico than at Punta Allen (J.-P. Huchin-Mian et al. unpubl. data). Together, these findings suggest that contact transmission rates of PaV1 may not be as high in nature as in the laboratory.

The persistence of PaV1 particles in sea water remains to be determined, but other viruses that infect aquatic invertebrates remain infective after several days in the water (e.g. white spot syndrome virus: Hossain et al. 2004; invertebrate iridescent virus 6 [IIV-6]: Hernández et al. 2005; yellow head virus: Ma et al. 2009). Viruses are prone to damage by solar ultraviolet radiation (UVR) (e.g. Wilhelm et al. 2003, Häder et al. 2007) but, at least in terrestrial ecosystems, the persistence of pathogenic viruses can be greatly influenced by the architecture of plants (via the degree of shading) in conjunction with habitat exposure to UVR (Duffey et al. 1995, Raymond et al. 2005, Cory \& Hoover 2006). Marine flora can act as a reservoir for pathogenic bacteria and fungi (Fuller et al. 1964, Mahmud et al. 2007, Small \& Pagenkopp 2011) and could also be a reservoir for pathogenic viruses. For example, Hernández et al. (2005) found that particles of IIV-6 in water underwent a more rapid loss of activity under direct sunlight $(99.99 \%$ reduction of original activity over a period of $36 \mathrm{~h}$ ) than in the shade $(97 \%$ reduction over a period of $60 \mathrm{~h}$ ). If $\mathrm{PaV} 1$ particles are transmitted through water in nature, then their persistence might also be influenced by habitat exposure to UVR and the degree of shading provided by the local marine vegetation.

This notion, which remains to be tested, could partially explain the lower levels of prevalence of the PaV1 disease in all benthic phases of Panulirus argus occupying casitas over the shallower and less vegetated habitats of Vigía Chico, relative to the deeper and more vegetated habitats in Punta Allen and Los
Cayos, as well as the high spatial variability in PaV1 prevalence recorded in other locations (e.g. Florida Bay: Behringer et al. 2011; Gulf of Batabanó, Cuba: Cruz-Quintana et al. 2011). Moreover, this notion could also partially explain why the asocial, early juveniles of $P$. argus, which dwell in the marine vegetation, exhibit the highest levels of clinical and subclinical PaV1-infection.

Acknowledgements. We thank the members of the Sociedad Cooperativa 'Pescadores de Vigía Chico' for allowing us to sample their fishing campos and for providing logistic support; Á. Fuentes-Breña, T. Arrúa-Ortiz, and M. Ley for their help in field activities; the Consejo Nacional de Ciencia y Tecnología, (CONACYT, México) for providing funds for this study (project No. 82724-Q) and postgraduate studentships for R.I.C.Z. (No. 26243) and J.P.H.M. (No. 190532), and the Comisión Nacional de Acuacultura y Pesca (CONAPESCA, México) for issuing annual permits to sample lobsters.

\section{LITERATURE CITED}

Anscombe FJ (1950) Sampling theory of the negative binomial and logarithmic series distribution. Biometrika 37: 358-382

Arce AM, Aguilar-Dávila W, Sosa-Cordero E, Caddy JF (1997) Artificial shelters (casitas) as habitats for juvenile spiny lobsters Panulirus argus in the Mexican Caribbean. Mar Ecol Prog Ser 158:217-224

Arellano-Méndez LU, Liceaga-Correa MA, Herrera-Silveira JA, Hernández-Núñez H (2011) Impacto por huracanes en las praderas de Thalassia testudinum (Hydrocharitaceae) en el Caribe Mexicano. Rev Biol Trop 59: 385-401

Behringer DC, Butler MJ (2010) Disease avoidance influences shelter use and predation in Caribbean spiny lobster. Behav Ecol Sociobiol 64:747-755

Behringer DC, Butler MJ, Shields JD (2006) Ecology: avoidance of disease by social lobsters. Nature 441:421

Behringer DC, Butler MJ VI, Shields JD, Moss J (2011) Review of Panulirus argus virus 1 - a decade after its discovery. Dis Aquat Org 94:153-160

Bez N (2000) On the use of Lloyd's index of patchiness. Fish Oceanogr 9:372-376

Bliss CI, Fisher RA (1953) Fitting the negative binomial distribution to biological data and note on the efficient fitting of the negative binomial. Biometrics 9:176-200

Briones-Fourzán P, Lozano-Álvarez E (2001) Effects of artificial shelters (casitas) on the abundance and biomass of juvenile spiny lobsters Panulirus argus in a habitat-limited tropical reef lagoon. Mar Ecol Prog Ser 221:221-232

Briones-Fourzán P, Lozano-Álvarez E, Eggleston DB (2000) The use of artificial shelters (casitas) in research and harvesting of Caribbean spiny lobsters in Mexico. In: Phillips BF, Kittaka J (eds) Spiny lobsters: fisheries and culture, 2nd edn. Blackwell, Oxford, p 420-446

> Briones-Fourzán P, Lozano-Álvarez E, Negrete-Soto F, Barradas-Ortiz C (2007) Enhancement of juvenile Caribbean spiny lobsters: an evaluation of changes in multiple response variables with the addition of large artificial shelters. Oecologia 151:401-416 
Briones-Fourzán P, Magallón-Gayón E, Lozano-Álvarez E (2012) Increased reproductive opportunity: a potential benefit of seasonal aggregation for a little-gregarious and highly sedentary spiny lobster. Mar Biol Res (in press)

Burnham KP, Anderson DR (2002) Model selection and multi-model inference, 2nd edn. Springer, New York, NY

- Burnham KP, Anderson DR, Huyvaert KP (2011) AIC model selection and multimodel inference in behavioral ecology: some background, observations, and comparisons. Behav Ecol Sociobiol 65:23-35

- Butler MJ VI, Herrnkind WF (1997) A test of recruitment limitation and the potential for artificial enhancement of spiny lobster (Panulirus argus) populations in Florida. Can J Fish Aquat Sci 54:452-463

Butler MJ, Behringer DC, Shields JD (2008) Transmission of Panulirus argus virus 1 (PaV1) and its effect on the survival of juvenile Caribbean spiny lobster. Dis Aquat Org 79:173-182

> Candia-Zulbarán RI, Briones-Fourzán P, Lozano-Álvarez E (2012) Variability in clinical prevalence of PaV1 in Caribbean spiny lobsters occupying commercial casitas over a large bay in Mexico. Dis Aquat Org 100:125-133

Childress MJ, Herrnkind WF (2001) The guide effect influence on the gregariousness of juvenile Caribbean spiny lobsters. Anim Behav 62:465-472

Cory JS, Hoover K (2006) Plant-mediated effects in insectpathogen interactions. Trends Ecol Evol 21:278-286

Cruz Quintana Y, Rodríguez Canul R, Vidal Martínez VM (2011) First evidence of Panulirus argus Virus 1 (PaV1) in spiny lobster from Cuba and clinical estimation of its prevalence. Dis Aquat Org 93:141-147

Duffey SS, Hoover K, Bonning BC, Hammock BD (1995) The impact of host-plant on the efficacy of baculoviruses. In: Roe M, Kuhr RJ (eds) Reviews in pesticide toxicology, Vol 3. CTI Toxicology Communications, Raleigh, NC, p 137-275

Eggleston DB, Lipcius RN (1992) Shelter selection by spiny lobster under variable predation risk, social conditions, and shelter size. Ecology 73:992-1011

> Eggleston DB, Lipcius RN, Miller DL, Cobá-Cetina L (1990) Shelter scaling regulates survival of juvenile Caribbean spiny lobster Panulirus argus. Mar Ecol Prog Ser 62: 79-88

Eggleston DB, Lipcius RN, Grover JL (1997) Predator and shelter-size effects on coral reef fish and spiny lobster prey. Mar Ecol Prog Ser 149:43-59

Enríquez S, Pantoja-Reyes N (2005) Form-function analysis of the effect of canopy morphology on leaf self-shading in the seagrass Thalassia testudinum. Oecologia 145: 235-242

Fisher RA (1941) The negative binomial distribution. Ann Eugen 11:182-187

Fuller MS, Fowles BE, McLaughlin D (1964) Isolation and pure culture study of marine phycomycetes. Mycologia 56:745-756

Gristina M, Fiorentino F, Garofalo C, Badalamenti F (2009) Shelter preference in captive juveniles of European spiny lobster Palinurus elephas (Fabricius, 1787). Mar Biol 156:2097-2105

> Häder DP, Kumar HD, Smith RC, Worrest RC (2007) Effects of solar UV radiation on aquatic ecosystems and interactions with climate change. Photochem Photobiol Sci 6: 267-285

> Hernández A, Marina CF, Valle J, Williams T (2005) Persis- tence of invertebrate iridescent virus 6 in tropical artificial aquatic environments. Arch Virol 150:2357-2363

> Herrnkind WF, Childress MJ, Lavalli KL (2001) Cooperative defence and other benefits among exposed spiny lobsters: inferences from group size and behaviour. Mar Freshw Res 52:1113-1124

Hobbs NT, Hillborn R (2006) Alternatives to statistical hypothesis testing in ecology: a guide to self-teaching. Ecol Appl 16:5-19

> Horner AJ, Nickles SP, Weissburg MJ, Derby CD (2006) Source and specificity of chemical cues mediating shelter preference of Caribbean spiny lobsters (Panulirus argus). Biol Bull (Woods Hole) 211:128-139

Hossain MS, Otta S, Chakraborty A, Kumar HS, Karunasagar I, Karunasagar I (2004) Detection of WSSV in cultured shrimps, captured brooders, shrimp postlarvae and water samples in Bangladesh by PCR using different primers. Aquaculture 237:59-71

Hurlbert SH (1990) Spatial distribution of the montane unicorn. Oikos 58:257-271

Johnson JB, Omland KS (2004) Model selection in ecology and evolution. Trends Ecol Evol 19:101-108

Kenney AJ, Krebs CJ (2002) EcoMeth 6.1: programs for ecological methodology. Exeter Software, New York, NY

Kinlaw AE (2006) Burrow dispersion of central Florida armadillos. Southeast Nat 5:523-534

Lipcius RN, Eggleston DB, Miller DL, Luhrs TC (1998) The habitat-survival function for Caribbean spiny lobster: an inverted size effect and non-linearity in mixed algal and seagrass habitats. Mar Freshw Res 49:807-816

> Lloyd M (1967) Mean crowding. J Anim Ecol 36:1-30

> Lozano-Álvarez E, Briones-Fourzán P (2001) Den choice and occupation patterns of shelters by two sympatric lobster species, Panulirus argus and Panulirus guttatus, under experimental conditions. Mar Freshw Res 52:1145-1155

Lozano-Álvarez E, Spanier E (1997) Behaviour and growth of captive spiny lobsters (Panulirus argus) under the risk of predation. Mar Freshw Res 48:707-713

Lozano-Álvarez E, Briones-Fourzán P, Phillips BF (1991) Fishery characteristics, growth, and movements of the spiny lobster Panulirus argus in Bahía de la Ascensión, Mexico. Fish Bull 89:79-89

> Lozano-Álvarez E, Briones-Fourzán P, Ramírez-Estévez A, Placencia-Sánchez D, Huchin-Mian JP, Rodríguez-Canul R (2008) Prevalence of Panulirus argus Virus 1 (PaV1) and habitation patterns of healthy and diseased Caribbean spiny lobsters in shelter-limited habitats. Dis Aquat Org 80:95-104

Lozano-Álvarez E, Meiners C, Briones-Fourzán P (2009) Ontogenetic habitat shifts affect performance of artificial shelters for Caribbean spiny lobsters. Mar Ecol Prog Ser 396:85-97

> Lozano-Álvarez E, Briones-Fourzán P, Álvarez-Filip L, Weiss HM, Negrete-Soto F, Barradas-Ortiz C (2010) Influence of shelter availability on interactions between Caribbean spiny lobsters and moray eels: implications for artificial lobster enhancement. Mar Ecol Prog Ser 400: 175-185

Ma H, Overstreet RM, Jovonovich JA (2009) Daggerblade grass shrimp (Palaemonetes pugio): a reservoir host for yellow-head virus (YHV). J Invertebr Pathol 101:112-118

Mahmud ZH, Neogi SB, Kassu A, Wada T, Islam MS, Nair GB, Ota F (2007) Seaweeds as a reservoir for diverse Vibrio parahaemolyticus populations in Japan. Int J Food Microbiol 118:92-96 
Meyer-Rochow VB (1994) Light-induced damage to photoreceptors of spiny lobsters and other crustaceans. Crustaceana 67:95-109

Mintz JD, Lipcius RN, Eggleston DB, Seebo MS (1994) Survival of juvenile Caribbean spiny lobster: effects of shelter size, geographic location, and conspecific abundance. Mar Ecol Prog Ser 112:255-266

Newcombe RG (1998) Two-sided confidence intervals for the single proportion: comparison of seven methods. Stat Med 17:857-872

Phillips BF, Melville-Smith R (2006) Panulirus species. In: Phillips BF (ed) Lobsters: biology, management, aquaculture and fisheries. Blackwell Scientific, Oxford, p 359-384

Randall JE (1967) Food habits of reef fishes of the West Indies. Stud Trop Oceanogr 5:665-847

Ratchford SG, Eggleston DB (1998) Size- and scale-dependent chemical attraction contribute to an ontogenetic shift in sociality. Anim Behav 56:1027-1034

Raymond B, Hartley SE, Cory JS, Hails RS (2005) The role of food plant and pathogen-induced behaviour in the persistence of a nucleopolyhedrovirus. J Invertebr Pathol 88: $49-57$

Shields JD (2011) Diseases of spiny lobsters: a review. J Invertebr Pathol 106:79-91

Shields JD, Behringer DC Jr (2004) A new pathogenic virus in the Caribbean spiny lobster Panulirus argus from the Florida Keys. Dis Aquat Org 59:109-118

Small HJ, Pagenkopp KM (2011) Reservoirs and alternate hosts for pathogens of commercially important crustaceans: a review. J Invertebr Pathol 106:153-164

Smith KN, Herrnkind WF (1992) Predation on early juvenile spiny lobsters Panulirus argus (Latreille): influence of size and shelter. J Exp Mar Biol Ecol 157:3-18

Sosa-Cordero E, Arce AM, Aguilar-Dávila W, Ramírez-

Editorial responsibility: Grant Stentiford,

Weymouth, UK
González A (1998) Artificial shelters for spiny lobster Panulirus argus (Latreille): an evaluation of occupancy in different benthic habitats. J Exp Mar Biol Ecol 229: $1-18$

Sosa-Cordero E, Liceaga-Correa MLA, Seijo JC (2008) The Punta Allen lobster fishery: current status and recent trends. In: Townsend R, Uchida H (eds) Case studies in fisheries self-governance. FAO Fish Tech Pap No. 504, FAO, Rome, p 149-162

Spanier E, Zimmer-Faust RK (1988) Some physical properties of shelter that influence den preference in spiny lobsters. J Exp Mar Biol Ecol 121:137-149

Thieltges DW, Poulin R (2008) Parasites and pathogens: avoidance. In: Encyclopedia of life sciences (ELS). John Wiley \& Sons, Chichester. Available at www.els.net

Weiss HM, Lozano-Álvarez E, Briones-Fourzán P, NegreteSoto F (2006) Using red light with fixed-site video cameras to study the behavior of the spiny lobster, Panulirus argus, and associated animals at night and inside their shelters. Mar Technol Soc J 40:86-95

Weiss HM, Lozano-Álvarez E, Briones-Fourzán P (2008) Circadian shelter occupancy patterns and predator-prey interactions of juvenile Caribbean spiny lobsters in a reef lagoon. Mar Biol 153:953-963

> White GC, Bennets RE (1996) Analysis of frequency count data using the negative binomial distribution. Ecology 77:2549-2557

> White GC, Eberhardt LE (1980) Statistical analysis of deer and elk pellet-group data. J Wildl Manag 44:121-131

> Wilhelm SW, Jeffrey WH, Dean AL, Meador J, Pakulski JD, Mitchell DL (2003) UV radiation induced DNA damage in marine viruses along a latitudinal gradient in the southeastern Pacific Ocean. Aquat Microb Ecol 31:1-8

Zar JH (1999) Biostatistical analysis, 4th edn. Prentice-Hall, Upper Saddle River, NJ

Submitted: August 31, 2011; Accepted: March 12, 2012 Proofs received from author(s): June 13, 2012 